\section{DIGITALCOMMONS}

@WAYNESTATE —

\section{Michigan Journal of Counseling: Research, Theory and Practice}

Volume $41 \mid$ Issue 1

Article 5

3-1-2014

\title{
Our New Editor
}

Amber Lange

Capella University

Follow this and additional works at: https://digitalcommons.wayne.edu/mijoc

\section{Recommended Citation}

Lange, A. (2014). Our New Editor, Michigan Journal of Counseling, 41(1), 53. doi:10.22237/mijoc/1393632240

This From the Editor is brought to you for free and open access by the Open Access Journals at DigitalCommons@WayneState. It has been accepted for inclusion in Michigan Journal of Counseling: Research, Theory and Practice by an authorized editor of DigitalCommons@WayneState. 


\section{OUR NEW EDITOR}

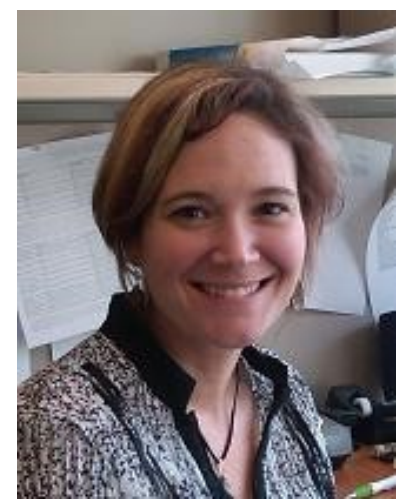

Amber Lange, Ph.D. is a Licensed Professional Counselor, a Certified Advanced Alcohol and Drug Counselor, and a National Certified Counselor. She is core faculty at Capella University and owns Bedford Behavioral Health in Lambertville, MI.

She has been teaching in higher education since 2004 and has taught master's and Ph.D. level counseling students since 2007. Her counseling expertise includes infidelity and betrayal, chemical dependency, and trauma. She has advanced academic training in research and measurement and quantitative statistics. She has over 100 peer-reviewed presentations and several publications. She has researched, published and utilized a therapy dog in counseling. She also is currently working with several school counselors who utilize a dog in the schools.

On a personal note, she has been married for 2 decades and has a daughter in college and a son in high school. Before her counseling career, she opened and ran a licensed drop-in child care center for stay-at-home moms. When she has free time, she boats on lake Erie with her husband and likes to cook. 